JeMAS 11 (2) (2016) xx-xx
Jitt://journal.unnes.ac.id/nju/index.php/kemas

\title{
KEJADIAN STUNTING DAN KEMATANGAN USIA TULANG PADA ANAK USIA SEKOLAH DASAR DI DAERAH PERTANIAN KABUPATEN BREBES
}

\author{
Apoina Kartini ${ }^{1 凶}$, Suhartono², Hertanto Wahyu Subagio³ ${ }^{3}$ Budiyono $^{2}$, Irene Max Emman ${ }^{4}$ \\ ${ }^{1}$ Departemen Gizi Kesehatan Masyarakat Fakultas Kesehatan Masyarakat UNDIP \\ ${ }^{2}$ Departemen Kesehatan Lingkungan Fakultas Kesehatan Masyarakat UNDIP \\ ${ }^{3}$ Bagian Gizi Fakultas Kedokteran UNDIP \\ ${ }^{4}$ SMF Radiologi RSUD Gunung Jati Kota Cirebon
}

\section{Info Artikel}

Sejarah Artikel:

Diterima 4 November 2015

Disetujui 16 Desember 2015

Dipublikasikan Januari 2016

Keywords:

Stunting; Bone-age;

Esticide; Elementary school

students; Agricultural area.

\section{DOI}

http://dx.doi.org/10.15294/

kemas.v11i1.3521

\begin{abstract}
Abstrak
Pestisida merupakan salah satu EDCs. Penelitian ini bertujuan menggambarkan kejadian stunting dan kematangan usia tulang pada anak usia Sekolah Dasar di Daerah Pertanian Kabupaten Brebes. Penelitian observasional tahun 2015 dengan pendekatan cross sectional. Sampel 66 siswa SD Dukuhlo 01 dan 02 berusia 8-12 tahun. Analisis statistik menggunakan uji chi-square. Kejadian stunting sebanyak $21,2 \%$ dan siswa yang mengalami keterlambatan usia tulang sebanyak 42,4\%. Proporsi siswa metabolit pestisida positif lebih banyak pada yang terlibat kegiatan pertanian $(29,2 \%)$ dibanding siswa yang tidak terlibat kegiatan pertanian $(5,6 \%)$. Kejadian stunting lebih banyak pada siswa dengan metabolit pestisida positif (26,7\%) dibanding yang negatif $(19,6 \%)$. Siswa kategori terlambat usia tulangnya lebih banyak pada yang metabolit pestisida positif $(46,7 \%)$ dibanding yang negatif $(41,2 \%)$. Kejadian stunting lebih banyak pada siswa dengan ke terlambatan usia tulang $(42,9 \%)$ dibanding siswa yang usia tulangnya termasuk kategori normal $(5,3 \%)$ dan berhubungan bermakna $(\mathrm{p}=0,001)$.
\end{abstract}

\section{STUNTING AND BONE-AGE MATURITY IN ELEMENTARY SCHOOL STUDENTS IN AGRICULTURE AREAS OF BREBES DISTRICT}

\begin{abstract}
Pesticide is an example of EDCs source. This study aimed to describe prevalence of stunting and bone-age maturity in elementary school students in agriculture areas of Brebes Districts. This was an observational study conducted in 2015 with cross sectional approach. Study subjects consisted of 66 students of SD Dukuhlo 01 and 02, ranged from 8 to 12 years old. chi-square test was used to analyzed the data. This study showed stunting prevalence among students was $21.2 \%$. There were $42.4 \%$ students underwent delayed bone-age maturiey. Proportion of students with positive pesticide metabolites were higher in those who involved in agriculture activities (29.2\%) compared to those who did not (5.6\%). Stunting was more prevalent in students with positive pesticide metabolites (26.7\%) compared to the negative ones (19.6\%). Students with delayed bone-age maturity were more frequent to be found with positive pesticide metabolites (46.7\%) compared to negative (41.2\%). Proportion of students with delayed bone-age maturiry (42.9\%) compared to normal (5,3\%). Stunting were significantly related to delayed bone-age maturity $(p=0.001)$.
\end{abstract}

(C) 2016 Universitas Negeri Semarang 


\section{Pendahuluan}

Stunting atau perawakan pendek (shortness) adalah suatu keadaan tinggi badan (TB) seseorang yang tidak sesuai dengan umur, yang penentuannya dilakukan dengan menghitung skor $\mathrm{Z}$ indeks Tinggi Badan menurut Umur (TB/U) (Gibson, 2005). Seseorang dikatakan stunting bila skor Z indeks $\mathrm{TB} / \mathrm{U}$-nya $<-2$ deviasi standar $(\mathrm{WHO}$ 2006). Kondisi stunting menggambarkan status gizi atau status kesehatan di masa lalu yang kurang baik dan menunjukkan adanya gangguan pertumbuhan linier pada seseorang. Stunting merupakan dampak dari asupan gizi yang kurang, baik dari segi kualitas maupun kuantitas, tingginya kesakitan, atau merupakan kombinasi dari keduanya. Kondisi tersebut sering dijumpai di negara dengan kondisi ekonomi kurang (Gibson, 2005). Penilaian kematangan usia tulang merupakan komponen kunci dalam evaluasi pertumbuhan anak karena dapat memberikan informasi tentang 'tempo' pola pertumbuhan anak (melambat atau mengalami percepatan) (Nilsson, 2005).

Masalah stunting pada anak perlu menjadi perhatian, karena merupakan refleksi kualitas sumberdaya manusia di masa mendatang. Beberapa penelitian menunjukkan adanya keterkaitan antara stunting dengan gangguan fungsi kognitif (Watanabe, 2005; Kar, 2008; Sokolovic, 2014) dan prestasi belajar anak usia sekolah (Brito, 2006). Penelitian lain membuktikan angka putus sekolah anak dengan stunting lebih tinggi dibanding anak normal. Gangguan fungsi kognitif pada anak dengan stunting, dalam jangka panjang akan mempengaruhi potensi ekonomi mereka (Prendergast, 2014). Kondisi stunting pada masa anak pada umumnya berlanjut sampai dewasa dan akan mempengaruhi kapasitas kerja dan produktivitas mereka (Prendergast, 2014; the Lancet's series, 2008).

Masalah stunting, yang merupakan masalah pertumbuhan fisik secara linier, umumnya dikaitkan dengan gizi masa lalu yang tidak baik (buruk). Asupan zat gizi makro, seperti energi, protein, dan zat gizi mikro, seperti Zn yang kurang, terutama pada masa pertumbuhan, akan mengganggu proses pertumbuhan seorang anak yang berdampak pada stunting (pendek). Infeksi berulang (kronis), seperti infeksi saluran pernafasan akut (ISPA) dan diare, juga merupakan penyebab utama terjadinya gangguan tumbuhkembang pada anak. Status gizi buruk dan infeksi merupakan lingkaran setan yang diduga merupakan faktor determinan utama terjadinya masalah gangguan tumbuh-kembang anak, salah satunya adalah stunting. Permasalahan gizi buruk maupun infeksi sangat berkaitan dengan kondisi sosial-ekonomi dan lingkungan keluarga. Status ekonomi yang buruk menyebabkan ketidakmampuan keluarga untuk menyediakan asupan gizi yang cukup dan lingkungan rumah yang memenuhi syarat kesehatan. Kondisi lingkungan rumah yang buruk, seperti kondisi fisik rumah yang tidak memadai dan kepadatan hunian yang tinggi, merupakan kondisi awal (predisposing factor) yang membuat anak menjadi lebih rentan terhadap berbagai penyakit infeksi, sehingga memperberat atau bahkan penyebab utama terjadinya status gizi buruk (malnutrisi).

Berdasarkan teori dan beberapa hasil penelitian yang telah dilakukan, peran lingkungan kemungkinan tidak hanya sebatas sebagai predisposisi (yang mengawali), tapi dapat juga sebagai penyebab 'langsung' gangguan tumbuh-kembang anak. Penelitian pada anakusia 6-59bulan di Nepal menunjukkan bahwa faktor lingkungan yang merupakan faktor risiko stunting antara lain dapur tanpa ventilasi dan paparan pestisida (Paudel R, 2012). Beberapa bahan kimia yang terdapat di lingkungan dikenal sebagai endocrine disrupting chemicals (EDCs), yaitu bahan kimia yang dapat mengganggu fungsi endokrin (hormon) dalam tubuh (Diamanti-Kandarakis, 2009). Salah satu hormon yang berperan penting dalam proses tumbuh-kembang anak adalah hormon tiroid. Paparan oleh bahan kimia yang tergolong EDCs dapat mengganggu fungsi tiroid sehingga disebut juga sebagai thyroid disrupting chemicals (TDCs). Adanya gangguan fungsi tiroid berdampak terhadap tumbuhkembang seseorang (Crofton, 2008).

Hasil Riset Kesehatan Dasar (Riskesdas) tahun 2013 mendapatkan prevalensi stunting pada anak usia sekolah (5-12 tahun) di Indonesia mencapai 30,7\%. Prevalensi stunting pada anak usia yang sama di Jawa Tengah sebesar 28,6\% dan untuk Kabupaten Brebes 
prevalensinya mencapai $40,7 \%$, paling tinggi di antara kabupaten/kota lainnya di Jawa Tengah (Kemenkes, 2013).

Kabupaten Brebes merupakan salah satu kabupaten di Provinsi Jawa Tengah yang mengandalkan sektor pertanian sebagai sumber pendapatan asli daerah. Konsumsi pestisida di daerah tersebut merupakan salah satu yang tertinggi di Indonesia. Jenis komoditas pertanian bawang merah, yang merupakan andalan utama di Kabupaten Brebes, memerlukan penyemprotan pestisida 2-3 kali per minggu, bahkan setiap hari pada musim penghujan. Tujuan penelitian ini adalah mendiskripsikan kejadian stunting dan kematangan usia tulang pada anak usia Sekolah Dasar (SD) di daerah pertanian Kabupaten Brebes.

\section{Metode}

Penelitian dilakukan tahun 2015, merupakan penelitian observasional dengan pendekatan cross sectional. Variabel yang diukur dalam penelitian ini antara lain karakteristik subjek, keterlibatan dalam kegiatan pertanian, kematangan usia tulang, metabolit pestisida dalam urin dan kejadian stunting. Pengumpulan data dilakukan dengan wawancara, pemeriksaan tinggi badan subjek, pemeriksaan rontgen tulang tangan kiri, dan pemeriksaan laboratorium untuk mendeteksi adanya metabolit pestisida dalam urin. Kejadian stunting ditentukan berdasarkan nilai skor Z indeks Tinggi badan menurut umur (TB/U). Tinggi badan diukur dengan menggunakan stadiometer merek SECA 213. Subjek termasuk kategori stunting bila nilai skor $\mathrm{Z}$ indeks TB/U kurang dari -2 Standard Deviasi (<-2 $\mathrm{SD})$. Kematangan usia tulang diukur dengan pemeriksaan foto rontgen tangan sebelah kiri (tangan yang tidak aktif) yang dilakukan oleh laboratorium klinik CITO. Pemeriksaan metabolit pestisida dalam urin dilakukan di PT. Angler Biochemlab Surabaya.

Sampel penelitian sebanyak 66 siswa SD usia 8-12 tahun di SD Negeri Dukuhlo 01 dan 02 Kecamatan Bulakamba, Kabupaten Brebes. Pengolahan dan analisis data dilakukan dengan menggunakan komputer. Perangkat lunak yang dipakai adalah SPSS PC. Setelah data disunting, ditabulasi, dan dibersihkan (cleaning), dilakukan analisis data univariat dan bivariat. Analisis univariat disajikan dalam bentuk tabel distribusi frekuensi dan untuk menganalisis hubungan antara dua variabel dilakukan dengan uji chi-square. Penelitian ini telah mendapat persetujuan dari Komisi Etik Penelitian Kesehatan (KEPK) Fakultas Kedokteran Universitas Diponegoro dan RSUP dr. Kariadi Semarang.

\section{Hasil dan Pembahasan}

Sebanyak 66 subyek terpilih sebagai sampel penelitian dari SD Dukuhlo 01 dan 02 Kecamatan Bulakamba Kabupaten Brebes. Subyek laki-laki lebih banyak (51,5\%) dibanding perempuan. Pekerjaan kepala keluarga di bidang pertanian sebesar 37,9\%. Distribusi frekuensi karakteristik subyek tersaji dalam Tabel 1.

Tabel 1. Distribusi Frekuensi Karakteristik Subyek

\begin{tabular}{ll}
\hline \multicolumn{1}{c}{ Karakeristik subyek } & \multicolumn{1}{c}{$\mathbf{n = 6 6}$} \\
\hline $\begin{array}{l}\text { Umur, tahun, (rerata } \pm \text { SD; min- } \\
\text { maks) }\end{array}$ & $10,3 \pm 0,79 ; 8-12$ \\
\hline Jenis kelamin, $n(\%)$ & $34(51,5)$ \\
Laki-laki & $32(48,5)$ \\
Perempuan & \\
\hline Pekerjaan kepala keluarga, & \\
(\%) & $1(1,5)$ \\
Tidak bekerja & $15(22,7)$ \\
Buruh tani & $10(15,2)$ \\
Petani pemilik & $36(54,5)$ \\
Pedagang/wiraswasta & $4(6,1)$ \\
Lain-lain & \\
\hline
\end{tabular}

Sumber: Data Primer

Berdasarkan hasil pengukuran terdapat $21,2 \%$ siswa termasuk kategori stunting (pendek) dan sebanyak $42,4 \%$ siswa mengalami keterlambatan usia tulangnya. Siswa yang terlibat dalam kegiatan pertanian sebanyak $72,7 \%$ dan yang positif metabolit pestisida dalam urinnya sebanyak 22,7\% (Tabel 2).

Siswa yang hasil metabolit pestisida dalam urinnya positif lebih banyak pada yang terlibat dalam kegiatan pertanian $(29,2 \%)$ dibanding siswa yang tidak terlibat dalam kegiatan pertanian $(5,6 \%)$.

Kejadian stunting lebih banyak proporsinya pada siswa dengan metabolit pestisida uirn positif $(26,7 \%)$ dibanding yang negatif (19,6\%). Siswa kategori terlambat usia 
tulangnya lebih banyak proporsinya pada yang metabolit pestisida urinnya positif $(46,7 \%)$ dibanding yang negatif $(41,2 \%)$.

Tabel 2. Distribusi Frekuensi Variabel Penelitian

\begin{tabular}{lc}
\hline \multicolumn{1}{c}{ Variabel } & $\mathbf{n}(\%)$ \\
\hline Kejadian stunting & \\
Stunting (pendek) & $14(21,2)$ \\
Normal & $52(78,8)$ \\
\hline Kematangan usia tulang & \\
Terlambat & $28(42,4)$ \\
Sesuai umur & $38(57,6)$ \\
\hline Metabolit pestisida dalam urin & \\
Positif & $15(22,7)$ \\
Negatif & $51(77,3)$ \\
\hline Keterlibatan dalam pertanian & \\
Ya & $48(72,7)$ \\
Tidak & $18(27,3)$ \\
\hline
\end{tabular}

Sumber: Data Primer

Tabel 3. Perbedaan Proposi Hasil Metabolit Pestisida Urin Menurut Keterlibatan dalam Pertanian

\begin{tabular}{lccc}
\hline \multirow{2}{*}{$\begin{array}{c}\text { Keterlibatan } \\
\text { dalam } \\
\text { pertanian }\end{array}$} & \multicolumn{2}{c}{$\begin{array}{c}\text { Metabolit pestisida dalam } \\
\text { urin }\end{array}$} & p \\
\cline { 2 - 3 } \cline { 2 - 2 } & Positif & Negatif & \\
\hline Ya & $14(29,2 \%)$ & $34(70,8 \%)$ & 0,087 \\
Tidak & $1(5,6 \%)$ & $17(94,4 \%)$ & \\
\hline
\end{tabular}

Sumber: data primer

Tabel 4. Perbedaan Proposi Kejadian Stunting dan Kematangan Usia Tulang Menurut Hasil Metabolit Pestisida dalam Urin

\begin{tabular}{lccc}
\hline \multirow{2}{*}{ Variabel } & \multicolumn{2}{c}{$\begin{array}{c}\text { Metabolit pestisida } \\
\text { dalam urin }\end{array}$} & p \\
\cline { 2 - 3 } & Positif & Negatif & \\
\hline $\begin{array}{l}\text { Kejadian stunting } \\
\text { Stunting (pendek) }\end{array}$ & $4(26,7 \%)$ & $10(19,6 \%)$ & 0,819 \\
Normal & $11(73,3 \%)$ & $41(80,4 \%)$ & \\
\hline $\begin{array}{l}\text { Kematangan usia } \\
\text { tulang }\end{array}$ & $7(46,7 \%)$ & $21(41,2 \%)$ & \\
$\begin{array}{l}\text { Terlambat } \\
\text { Sesuai umur }\end{array}$ & $8(53,3 \%)$ & $30(58,8 \%)$ & 0,935 \\
\hline
\end{tabular}

Sumber: data primer

Kejadian stunting lebih banyak pada siswa dengan keterlambatan usia tulang $(42,9 \%)$ dibanding siswa yang usia tulangnya termasuk kategori normal (5,3\%). Hasil uji Chi-square menunjukkan terdapat hubungan bermakna $(p=0,001)$.

Hasil penelitian pada siswa usia SD

di daerah pertanian Kabupaten Brebes menunjukkan bahwa sebanyak $72,7 \%$ siswa terlibat dalam kegiatan pertanian, 21,2\% termasuk kategori stunting (pendek), 42,4\% mengalami keterlambatan usia tulang dan $22,7 \%$ terdeteksi positif metabolit pestisida dalam urin. Proporsi siswa yang stunting dan terlambat kematangan usia tulangnya lebih banyak pada siswa yang positif metabolit pestisida urinnya. Terdapat hubungan keterlambatan usia tulang dengan kejadian stunting.

Tabel 5. Hubungan Kematangan Usia Tulang dengan Kejadian Stunting

\begin{tabular}{llcl}
\hline & \multicolumn{2}{c}{ Kejadian stunting } & \\
\cline { 2 - 3 } $\begin{array}{c}\text { Kematangan } \\
\text { usia tulang }\end{array}$ & \multicolumn{1}{c}{ Stunting } & Normal & $\mathbf{p}$ \\
\hline $\begin{array}{l}\text { Terlambat } \\
\text { Tidak terlambat }\end{array}$ & $2(5,3 \%)$ & $36(94,7 \%)$ & $0,001^{*}$ \\
\hline
\end{tabular}

Sumber: data primer

Stunting atau 'perawakan pendek' ('shortness') adalah suatu keadaan kurangnya panjang badan atau tinggi badan seseorang terhadap umurnya, yang penentuannya dilakukan dengan menghitung skor $\mathrm{Z}$ indeks Tinggi Badan menurut Umur (TB/U) (Gibson, 2005). Seseorang dikatakan stunting bila nilai skor $\mathrm{Z}$ tinggi badan menurut umur (HAZ atau indeks $\mathrm{TB} / \mathrm{U}$ ) adalah kurang dari minus dua standar deviasi (-2 SD) (WHO, 2006). Stunting menunjukkan adanya gangguan pertumbuhan linier pada seseorang. Masalah stunting pada anak perlu menjadi perhatian, karena merupakan refleksi kualitas sumberdaya manusia di masa mendatang. Stunting merupakan indikator kesehatan anak yang memberikan gambaran dari sejarah gizi pada masa lalu, keadaan lingkungan dan sosial ekonomi (Gibson, 2005).

Stunting meningkatkan risiko dan angka kesakitan pada masa anak, khususnya di negaranegara sedang berkembang (The Lancet's Series 2008). Berkaitan dengan meningkatnya risiko dan angka kesakitan tersebut, stunting juga menyebabkan gangguan fisik maupun fungsional pada anak (The Lancet's Series, 2008). Stunting berkontribusi $14,5 \%$ terhadap kematian dan $12,6 \%$ terhadap gangguan kemampuan fungsional (disability adjusted life years) pada anak balita (The lancet's series, 
2008). Kondisi stunting diduga berhubungan dengan sistem imunitas. Penelitian di Afrika membuktikan adanya peningkatan insidens, derajat keparahan dan durasi (lama sakit) malaria pada kelompok anak dengan stunting (Verhoef, 2002).

Stunting merupakan hasil dari kekurangan gizi kronis yang menghambat pertumbuhan linier (Caulfield, 2006). Suatu kondisi yang mengganggu kemampuan individu untuk menyerap makanan dapat menyebabkan terjadinya gangguan pertumbuhan. Kegagalan pertumbuhan dapat disebabkan oleh tidak memadainya asupan dari satu atau lebih zat gizi termasuk energi, protein, atau mikronutrien seperti besi, seng, fosfor, vitamin D, vitamin A dan vitamin C. Masyarakat di negara berkembang biasanya mengalami kekurangan zat gizi mikro dalam asupan makan sehari-harinya. Seseorang yang mengalami kekurangan zat gizi besi dalam makanannya, biasanya juga berrisiko kekurangan zat gizi seng dan mungkin juga kalsium (Branca, 2002)

Konsumsi zat gizi makro, seperti energi, protein, dan zat gizi mikro, seperti $\mathrm{Zn}$, zat besi yang kurang, terutama pada masa pertumbuhan, akan mengganggu proses pertumbuhan seorang anak yang berdampak pada stunting (Mikhail et al. 2013). Selain faktor konsumsi makanan, stunting juga dipengaruhi oleh faktor genetik, yaitu tinggi badan orangtua (Ferreira, 2009; Candra, 2011). Beberapa penelitian juga menunjukkan bahwa riwayat Berat Badan Lahir Rendah (BBLR) merupakan faktor risiko stunting (Vitolo 2008; El-Taguri, 2008; Candra, 2011; Mardani, 2015). Penelitian di Iran membuktikan bahwa determinan utama stunting pada anak usia sekolah adalah berat badan lahir, usia ibu, dan tinggi badan ayah (Esfarjani, 2013). Infeksi berulang (kronis), seperti infeksi saluran pernafasan akut (ISPA) dan diare, juga merupakan penyebab utama terjadinya gangguan tumbuhkembang pada anak. Penelitian pada anak balita di Nepal menyimpulkan bahwa ISPA dan diare merupakan faktor risiko stunting (Paudel, 2012). Status sosial-ekonomi yang buruk menyebabkan keluarga tidak mampu menyediakan asupan gizi yang cukup dan lingkungan rumah yang memenuhi syarat kesehatan. Kondisi ini merupakan faktor predisposisi yang membuat anak menjadi lebih rentan terhadap berbagai penyakit infeksi, sehingga memperberat atau bahkan penyebab utama terjadinya gangguan tumbuh-kembang anak (Nandy, 2004).

Gangguan pertumbuhan dapat juga disebabkan oleh faktor lingkungan, salah satunya adalah adanya peran dari bahan kimia berbahaya di lingkungan yang dapat menganggu fungsi hormon (Endocrine disrupting chemicals/ EDCs). Pestisida merupakan salah satu bahan kimia yang sering digunakan dalam kegiatan pertanian dan tergolong sebagai EDCs (Diamanti-Kandarakis, 2009).

Pestisida adalah substansi yang digunakan untuk mencegah atau membunuh hama (pest), yakni organisme yang bersaing untuk mendapatkan makanan, mengganggu kenyamanan, atau berbahaya bagi kesehatan manusia. Penggunaan pestisida sudah sangat meluas, berkaitan dengan dampak positifnya, yaitu meningkatnya produksi pertanian dan menurunnya penyakit-penyakit yang penularannya melalui perantaraan makanan (food-borne diseases) atau pun vektor (vectorborne diseases) (Weiss, 2004). Idealnya, pestisida mempunyai efek toksik hanya pada organisme targetnya, yaitu hama. Namun, pada kenyataannya, sebagian besar bahan aktif yang digunakan sebagai pestisida tidak cukup spesifik toksisitasnya, sehingga berdampak negatif terhadap kesehatan (manusia) (Costa 2008). Sampai saat ini, terdapat sekitar 20.000 jenis produk pestisida dengan sekitar 900 jenis bahan aktif yang telah terdaftar, dengan tujuan pemakaian sebagai insektisida, mitisida, herbisida, rodentisida, nematosida, fungisida, fumigan, pengawet kayu, dan pengatur pertumbuhan tanaman (plant growth regulator) (Weiss, 2004).

Anak yang lahir dan dibesarkan di daerah pertanian berisiko mengalami paparan pestisida sejak kecil, bahkan sejak di dalam kandungan, karena sebagian besar WUS, termasuk ibu hamil, ikut terlibat dalam kegiatan pertanian. Penelitian di Cina membuktikan bahwa riwayat paparan pestisida golongan organofosfat pada ibu hamil merupakan faktor risiko kejadian gangguan tumbuh-kembang pada neonatus (Zhang, 2014). Pada anak usia SD, paparan 
pestisida dapat terjadi secara langsung yakni karena keterlibatan mereka dalam kegiatan pertanian, atau secara tidak langsung yakni melalui kontak dengan lingkungan, baik air, tanah, maupun makanan yang terkontaminasi oleh residu pestisida.

Kematangan usia tulang merupakan komponen kunci dalam evaluasi pertumbuhan anak. Penilaian kematangan tulang ditentukan melalui pengukuran "Bone Age" (BA), yaitu pemeriksaan foto rontgen tulang pergelangan tangansebelahkiri.Pengerasantulangtrabekular terjadi dalam pola yang dapat diprediksi, sehingga penilaian kematangan tulang dapat dilakukan pada beberapa pusat osifikasi kemudian dibandingkan gambaran radiografi standar untuk laki-laki dan perempuan. BA kemudian dapat dibandingkan dengan usia kronologis individu sebagai indikator kecepatan pertumbuhan, potensi pertumbuhan selanjutnya, dan dengan menggunakan \pm SD reference dapat disimpulkan termasuk kategori terlambat (delay) atau normal. Pemeriksaan foto rontgen tunggal pada tangan kiri dianggap representatif untuk menilai pusat osifikasi pada umumnya dan dengan demikian menghindari paparan radiasi untuk pemeriksaan radiografi seluruh tulang (Nilsson, 2005).

Pemeriksaan metabolit pestisida dalam urin merupakan metode pemeriksaan yang cukup sensitif dan reliabel untuk menentukan adanya paparan pestisida pada seseorang (Egeghy, 2011). Metode pemeriksaan tersebut tidak invasif, sehingga sangat memungkinkan dilakukan pada anak, meskipun ada keterbatasan yakni hanya menggambarkan paparan saat ini, karena pestisida golongan organofosfat cepat dimetabolisme dan diekskresi dari dalam tubuh, dengan waktu paruh 2 jam sampai beberapa hari (Wessels, 2003).

Beberapa hormon yang berperan dalam proses pertumbuhan antara lain hormon tiroid, Growth Hormone (GH) dan Insulinelike Growth Factor (IGF-1). Hormon tiroid adalah pengatur metabolisme tubuh dan sangat penting untuk fungsi sebagian besar sistem organ tubuh. Status tiroid normal pada masa anak diperlukan untuk pertumbuhan normal dan perkembangan saraf. Gangguan fungsi tiroid yang dapat dideteksi pada tahap awal akan membantu hasil pengobatan yang baik (Huang, 2010). Paparan oleh bahan kimia yang tergolong EDCs dapat mengganggu fungsi tiroid sehingga disebut juga sebagai thyroid disrupting chemicals (TDCs) (Crofton, 2009). Adanya gangguan fungsi tiroid dapat berdampak terhadap tumbuh-kembang seseorang.

Penelitian pada binatang (Jeong, 2006) dan pada manusia (Zaidi, 2000; Crofton, 2008; Suhartono, 2012) membuktikan bahwa paparan pestisida dapat mengganggu fungsi tiroid, yaitu suatu kondisi kelenjar tiroid tidak dapat memproduksi hormon $\mathrm{T}_{4}$ dan $\mathrm{T}_{3}$ yang cukup untuk memenuhi kebutuhan tubuh. Kadar hormon tiroid yang rendah dalam masa pertumbuhan dapat menyebabkan terjadinya stunting (Australian Paediatric Endocrinology Group, 2011). Pada anak dengan hipotiroidisme akan terjadi keterlambatan pertumbuhan (Rose, 2005).

Growth Hormone (GH) dan Insulinelike Growth Factor (IGF-1), merupakan hormon yang sangat diperlukan dalam proses pertumbuhan dan metabolisme selama kehidupan. GH sangat diperlukan dalam pertumbuhan pada masa bayi, dan juga berperan penting di jaringan perifer terhadap proses metabolisme energi, komposisi tubuh, metabolisme tulang, sistem imun, dan fungsi otot. Di Sistem Saraf Pusat (SSP) GH berpengaruh terhadap fungsi appetite (nafsu makan), kognisi dan tidur (Skottner, 2012). Sementara itu, IGF-1 merupakan hormon polipeptida yang berfungsi sebagai mitogen dan stimulator proliferasi sel dan berperan penting dalam proses perbaikan dan regenerasi jaringan. IGF-1 juga memediasi proses anabolik protein dan meningkatkan aktivitas GH untuk pertumbuhan linier (Skottner, 2012; Laron, 2001). Paparan bahan toksik dari lingkungan juga dapat mengganggu sintesis dan/atau sekresi hormon pertumbuhan (Insulin-like Growth Hormone/IGF-1) (Boada LD, 2007). Penelitian di Spanyol menunjukkan bahwa kadar IGF1 serum anak laki-laki usia 6-15 tahun yang terpapar pestisida golongan organoklorin lebih rendah secara signifikan dibanding yang tidak terpapar (Zumbado, 2010). Kadar IGF-1 dalam serum berhubungan dengan gangguan pertumbuhan. Hasil penelitian pada anak 
prasekolah di Senegal menunjukkan bahwa terdapat hubungan antara kadar IGF-1 dengan stunting.

\section{Penutup}

Kejadian stunting sebanyak $21,2 \%$ dan siswa yang mengalami keterlambatan usia tulang sebanyak $42,4 \%$. Proporsi siswa yang hasil metabolit pestisida dalam urinnya positif lebih banyak pada yang terlibat dalam kegiatan pertanian $(29,2 \%)$ dibanding siswa yang tidak terlibat dalam kegiatan pertanian (5,6\%). Proporsi stunting lebih banyak pada siswa dengan metabolit pestisida urin positif $(26,7 \%)$ dibanding yang negatif (19,6\%). Siswa dengan usia tulang termasuk kategori terlambat lebih banyak proporsinya pada yang metabolit pestisida urin positif $(46,7 \%)$ dibanding yang negatif $(41,2 \%)$. Kejadian stunting lebih banyak pada siswa yang mengalami keterlambatan usia tulang $(42,9 \%)$ dibanding siswa dengan usia tulang normal (5,3\%). Terdapat hubungan bermakna usia tulang dengan kejadian stunting $(p=0,001)$.

\section{Ucapan Terima Kasih}

Terima kasih kepada Direktorat Riset dan Pengabdian Masyarakat Kemenristek Dikti yang telah memberikan dana melalui penelitian Hibah Kompetensi Tahun 2015 serta Lembaga Penelitian dan Pengabdian kepada Masyarakat (LPPM) Universitas Diponegoro yang telah memfasilitasi kegiatan penelitian ini.

\section{Daftar Pustaka}

Boada LD, et al. 2007. Serum Levels of Insulinlike Growth Factor-I in Relation to Organochlorine Pesticides Exposure. Growth Horm IGF Res, 17: 506-511.

Branca F, Ferrari M, 2002. Impact of Micronutrient Deficiencies on Growth: The Stunting Syndrome. Ann Nutr Metab 2002,46(suppl 1):8-17.

Brito GNO and de Onis M, 2006. Growth Status and Academic Performance in Brazilian School Age Children. Growth Retardation Impairs Mathematical, but not Reading and Spelling Abilities. Arq Neuropsiquiatr; 64(4):921-925.

Candra A, Puruhita N, and Susanto JC, 2011. Risk Factors of Stunting Among 1-2 Years Old Children in Semarang City. Media Medika Indonesiana, 45(3):206-212.
Caulfield LE, et al. 2006. Stunting, Wasting, and Micronutrient Deficiency Disorders. In: Disease control priorities in developing countries, 2nd edition. World Bank Group, Washington (DC).

Costa LG, 2008 Toxic effects of pesticides. In: L.J. Casarett \& J. Doull, eds. 2008. Toxicology. The basic science of poisons. $7^{\text {th }}$ ed. New York: Macmillan Publishing Company: 883-930.

Crofton KM, 2008. Thyroid Disrupting Chemicals: Mechanisms and Mixtures. International Journal of Andrology, 31(2): 209-223.

Diamanti-Kandarakis E, et al. 2009. Endocrinedisrupting Chemicals. An Endocrine Society Scientific Statement. Endocrine Reviews, 30(4): 293-342.

Egeghy PP, et al. 2011. Review of Pesticide Urinary Biomarker Measurements from Selected US EPA Children's Observational Exposure Studies. Int. J. Environ. Res. Public Health; 8:1727-1754.

El-Taguri A, et al. 2008. Risk Factors for Stunting Among Under-fives in Libya. Public Health Nutrition, 12(8):1141-1149.

Esfarjani F, Roustaee R, Mohammadi F, Esmaillzadeh A, 2013. Determinants of Stunting in School Aged Children of Tehran, Iran. International Journal of Preventive Medicine, 4(2):173-179.

Ferreira HS, et al. 2009. Short Stature of Mothers from an Area Endemic for Undernutrition is Associated with Obesity, Hypertension and Stunted Children: a Population-Based Study in the Semi-arid Region of Alagoas, Northeast Brazil. British Journal of Nutrition, 101: 1239-1245.

Gibson RS, 2005. Principles of Nutritional Assessment, Second Edition. Oxford University Press, Inc., New York.

Huang SA, 2010. Thyroid. In: Pediatric practice, Endocrinology. (editors: Kappy MS, Allen DB, Geffner ME). The McGraw-Hill Companies, Inc. New York: 107-129.

Jeong S, et al. 2006. Effect of Chlorpyrifos-methyl on Steroid and Thyroid Hormones in Rat F0and F1- Generations. Toxicology Division. National Veterinary Research and Quarantine Service. Copyright $\odot$ Elsevier Ireland Ltd.

Kar BR, Rao SL and Chandramouli BA, 2008. Cognitive Development in Children with Chronic Protein Energy Malnutrition. Behavioral and Brain Function: 4: 31.

Kementerian Kesehatan RI, Badan Litbangkes, 2013. Riset Kesehatan Dasar, Riskesdas 2013.

Laron Z, 2001. Insulin-like Growth Factor 1 (IGF1): a Growth Hormone. J Clin Pathol: Mol Pathol; 54:311-316. 
Mardani RAD, Wetasin K, dan Suwanwaiphatthana W, 2015. Faktor Prediksi yang Mempengaruhi Terjadinya Stunting pada Anak Usia di Bawah Lima Tahun. Jurnal Kemas, 11(1):1-7.

Mikhail WZA, et al. 2013. Effect of Nutritional Status on Growth Pattern of Stunted Preschool Children in Egypt. Academic Journal of Nutrition 2(1):01-09.

Nandy S, et al. 2005. Poverty, child Undernutrition and Morbidity: New Evidence from India. Bulletin of the World Health Organization; 83(3):210-216.

Nilsson O, et al. 2005. Endocrine Regulation of the Growth Plate. Hormone Research, 64:157165.

Paudel R, et al. 2012. Risk Factors for Stunting Among Children: a Community Based Case Control Study in Nepal. Kathmandu University Medical Journal, 10(3):18-24.

Prendergast AJ, Humphrey JH, 2014. The Stunting Syndrome in Developing Countries. Paediatrics and International Child Health 2014 Vol. 000 No. 000:1-16.

Rose SR, Vogiatzi MG and Copeland KC, 2005. A General Pediatric Approach to Evaluating a Short Child. Pediatrics in Review, vol. 26:410419.

Skottner A, 2012. Biosynthesis of Growth Hormone and Insulin-Like Growth Factor-I and the Regulation of their Secretion. The Open Endocrinology Journal, 6, (Suppl 1: M2) 3-12.

Sokolovic N, et al. 2014. Catch-up Growth Does not Associate with Cognitive Development in Indian school-age children. European Journal of Clinical Nutrition, 68:14-18.

Suhartono, et al. 2012. Pajanan Pestisida sebagai Faktor Risiko Hipotiroidisme pada Wanita Usia Subur di Daerah Pertanian. Media Medika Indonesiana, 46 (2):91-99.

The Lancet's series on Maternal and Child Undernutrition Executive Summary. 2008. (http://tc.iaea. org/tcweb/abouttc/tcseminar/ Sem6-ExeSum.pdf).

Verhoef H, et al. 2002. Stunting may Determine the
Severity of Malaria Associated Anemia in African Children. Pediatrics; 110:e48.

Vitolo MR, et al. 2008. Some Risk Factors Associated With Overweight, Stunting and Wasting among Children Under 5 Years Old. Jornal de Pediatria, 84 (3):251-257.

Watanabe K, et al. 2005. Early Childhood Development Interventions and Cognitive Development of Young Children in Rural Vietnam. The Journal of Nutrition, 135: 1918-1925.

Weiss B, Amler S \& Amler RW, 2004. Pesticides. Pediatrics, 113, pp.1030-1036.

Wessels D, Barr DB, and Mendola P, 2003. Use of Biomarkers to Indicate Exposure of Children to Organophosphate Pesticides: Implications for a Longitudinal Study of Children's Environmental Health. Environ Health Perspect 111:1939-1946.

WHO Multicentre Growth Reference Study Group, 2006. WHO Child Growth Standards: Length/ height-for-age, weight-for-age, weight-forlength,weight-for-height and body mass index-for-age: Methods and development. Geneva, World Health Organization.

Available at: http://www.who.int/ childgrowth/standards/technical report/en/ index.html

Zaidi SSA et al, 2000. Assessment of Thyroid Function in Pesticide Formulators. Human \& Experimental Toxicology, 19 (9), pp.497501.

Zhang Y, et L. 2014. Prenatal Exposure to Organophosphate Pesticides and Neuro Behavioral Development of Neonates: a Birth Cohort Study in Shenyang, China. PLoS ONE 9(2): e88491. doi:10.1371/journal. www. plosone.org.

Zumbado M, et al. 2010. Insulin-like Growth Factor-I (IGF-I) Serum Concentration in Healthy Children and Adolescents: Relationship to level of contamination by DDT-derivate pesticides. Growth Hormone \& IGF Research 20:63-67. 